Iraqi Journal of Industrial Research (IJOIR)

Journal homepage: http://ijoir.gov.iq

\title{
Transformation of Biodegradable Organic Municipal Solid Waste to Compost Using Stationary and Rotary Units
}

\author{
${ }^{1}$ Waleed Mohammed Abood*, ${ }^{1}$ Dhafer F. Ali, ${ }^{1}$ Firas S. Abass, ${ }^{2}$ Jathwa A. Al Ameen \\ ${ }^{1}$ Renewable Energy and Environment Research Center/ Corporation of Research and Industrial Development - \\ Iraq \\ ${ }^{2}$ College of Engineering, University of Baghdad - Iraq
}

\section{Article information}

\section{Article history:}

Received: June, 21, 2021

Accepted: September, 05, 2021

Available online: December, 14, 2021

Keywords:

C/N Ratio,

Composting process,

Organic matters

*Corresponding Author:

Waleed Mohammed Abood

dr.waleedabood@gmail.com

DOI:

https://doi.org/10.53523/ijoirVol8I3ID55

\begin{abstract}
This study aims to convert the municipal solid waste (MSW), which include garbage and chicken manure as raw biodegradable organic waste to produce a compost in order to transform these materials into recommended fertilizer. The principle of aerobic composting method is a waste oxidation through holding these mixed raw materials with a ratio of 1:1 garbage and chicken manure in two units of composting, rotary unit and stationary unit with recommended Carbon/Nitrogen ratio $\mathrm{C} / \mathrm{N}$ of $20: 1$ and $\mathrm{pH}$ of 6.5 with moisture content of about $40 \%$ by adding water during composting process and presence of oxygen naturally. The period time of composting process was 69 days to get normal temperature of compost bulk equal to ambient temperature and $\mathrm{pH}$ value as natural value using two composting units. The composting results during first 30 days shows the temperature values 59.5 and $55^{\circ} \mathrm{C}$ for rotary unit and stationary units that refers to microbial action of microorganism and decomposition of organic matter to energy as heat. The $\mathrm{pH}$ values were having acidic state during first week that refers to the formation of organic acids. The final compost characteristics show a $\mathrm{C} / \mathrm{N}$ ratio of 20.8 and 22.275 for rotary and stationary units, respectively with a decrease in $\mathrm{C} \%$ and $\mathrm{N} \%$, which refers to a successful composting process, where Nitrogen, Phosphor and Potassium NPK values were (1.428:1.719:4.508) \% for rotary unit and (1.361:0.419:3.884) \% for stationary unit and electrical conductivity of 5.5 and $6.04 \mathrm{mS} / \mathrm{cm}$ as acceptable value according to the recommended standard values.
\end{abstract}

\section{Introduction}

Increasing of human population and life requirements leads to a more consumption in natural resources and generation of waste. Generated solid wastes is referred to as municipal solid waste (MSW), which describe the stream of solid waste generated by households, commercial establishments, industries and institutions [1]. MSW consists of everyday items such as product packaging, grass clippings, furniture, clothing, bottles, food scraps, newspapers, appliances, paint and batteries [2], agricultural waste, and livestock manure. It does not include medical, commercial and industrial hazardous or radioactive wastes, which must be treated separately [1]. 
Solid waste management criteria involve three main stages, which are: collection at generation sources, transporting from source to sector collection sites and treatment were recycling or disposal of waste materials to reduce their impact on human health and environment [3]. The type of waste management actions that should be applied for suitable management of waste should be chosen according to the composition of the solid waste [4]. There are various techniques applied in solid waste treatment, for example, sanitary landfills, incineration, and gasification [3]. Improper waste management is detrimental to human health. Apart from being unsightly, it causes air pollution, affects water bodies when dumped into the water, as well as depletes the ozone layer when burnt, and hence, increasing the impact of climate change [5].

The conventional waste collection and disposal system in most developing countries consists of garbage trucks and open area dumping without an integrated system of management strategy which involves many options [6]. The 4R Strategy before the options of waste-to-energy, sanitary land filling, and composting, such as, reduction amount of generated solid waste, recycling of waste as raw material, recovery of material and reusing option.

The composting is a natural process that involves the aerobic biological decomposition of organic matters under controlled conditions. The stabilization of rich biodegradable organic solid waste (e.g., proteins, carbohydrates, and lipids) and plant nutrients (nitrogen, phosphorus, and potassium), which can be considered as a natural recycling of raw materials to their sources [7].

The composting process can avoid environmental effects [8]. Presenting a positive balance role when applied to enhance the soil as organic fertilizer [9]. The composting, as a modern way of treatment of municipal waste, is an exothermic process of biological oxidation, in the course of which the organic substrate is subjected to aerobic biodegradation under the influence of microorganisms in conditions of increased temperature and humidity.

In the process of biodegradation, the organic substrate undergoes physical, chemical, and biological transformations, where a stable humic final product is created [2]. The composting process stages includes [10]:

* First thermo-stage: The composting transform starts at standard condition of temperature and in the first days (1-2 days). The recorded temperature gradually reaches to $45^{\circ} \mathrm{C}$. This increase in temperature is caused by microbial action (bacteria and fungus) due to the exhaustion of carbon and nitrogen in the raw materials under exothermic conditions which leads to release energy as heat and a drop in $\mathrm{pH}$ to about 4-5 during 2-8 days.

* Second thermo-stage: This stage starts at a point when the raw material reaches to an end of the pervious stage at which temperature reaches higher than $45^{\circ} \mathrm{C}$. When the parent material reaches temperatures higher than $45^{\circ} \mathrm{C}$, the other microorganism that grow at higher temperatures will degrade the complex sources of $\mathrm{C}$ and $\mathrm{N}$ compound which lead to more exothermal condition and rising temperatures to $60^{\circ} \mathrm{C}$ and $\mathrm{pH}$ over 5 due to release of energy and production of ammonia during a month.

* Cooling stage: At the end of pervious stage, the cooling stage is started due to exhausting of $\mathrm{C}$ and $\mathrm{N}$ in the raw materials, where temperature drops again to a range of $40-45^{\circ} \mathrm{C}$, while $\mathrm{pH}$ remains slightly alkaline. Some fungi can be developed and even produce visible structures. This cooling stage is continued for several weeks.

* Compost production stage: This stage is started at the end of the above three stages, where the temperature reaches to ambient conditions, and $\mathrm{pH}$ is at neutralization range.

* Composting process is influenced by oxygen levels, particle sizes of the feedstock material, nutrient levels, moisture content, temperature, and $\mathrm{pH}$ value $[10,11,12]$.

* The composting process can occur under aerobic or anaerobic conditions, where aerobic condition is faster than anaerobic with an average of 15 times due to the availability of free oxygen.

* The physical shape of the raw material (solid waste), where particle size plays an affecting role during the composting process where smaller size raw material enhances transformation rate of composting process, positively.

* Nutrient availability in the raw material is important parameter for microbial activity during composting stages to reach efficient compost. This nutrient includes carbon-nitrogen as $\mathrm{C} / \mathrm{N}$ ratio, phosphorus and potassium.

* Water content as moisture plays a mobile phase for substance transporting in composting bulk which helps to deliver the nutrient for microorganisms. The acceptable range of moisture in compost process is about $40-45$ w/w. Low moisture causes nutrient shortage and high moisture causes leachate problem. 
* The most effective composting temperatures are in between $45-60^{\circ} \mathrm{C}$. If recorded temperatures are below this range, the microorganisms become inactive to decompose organic waste. If temperatures are greater than $60^{\circ} \mathrm{C}$, some microorganisms are affected negatively or killed, which leads to reduce composting rate.

* $\mathrm{pH}$ value plays a main role during composting process. When the $\mathrm{pH}$ value is 6 , the decomposition of organic solids will be affected due to microorganisms, especially bacteria that die off. If the $\mathrm{pH}$ value reaches 9 , production of ammonia from nitrogen will start causing $\mathrm{N}$ shortage as nutrient for organisms and this will affect the decomposition rate during composting process.

Composting procedure is done as open system as piles, stationary holding containers or turning horizontal/vertical container [13] with aeration by air system [14] or mechanical turning aeration where collection leachate system must be available for leachate control $[10,15]$.

The aim of this study is to transform garbage (food waste) and chicken manure as biodegradable solid waste to compost in holding containers and rotary vessel technique with mechanical aeration. The $\mathrm{C} / \mathrm{N}$ ratio, temperature, $\mathrm{pH}$ value, moisture and NPK concentration are evaluated for raw materials and produced compost according to standard values to evaluate the quality of compost.

\section{Experimental Procedure}

The raw materials that were being used as composting source are garbage (house hold solid waste that contains food waste after separation glass, plastic and non-biodegradable wastes) and chicken manure (faeces of chicken). 1:1 mixed wastes of two types were used as raw feedstock as shown in Table (1) to improve acceptable $\mathrm{C} / \mathrm{N}$ ratio to start composting process.

Table (1). Specifications of feedstock as raw organic waste.

\begin{tabular}{|c|c|c|c|}
\hline Parameters & Garbage & $\begin{array}{c}\text { Chicken } \\
\text { manure }\end{array}$ & $\begin{array}{c}\text { Garbage: } \\
\text { Chicken } \\
\text { manure } \\
\mathbf{1 : 1}\end{array}$ \\
\hline $\begin{array}{c}\text { Carbon } \\
\text { content C\% }\end{array}$ & 46.71 & 47.35 & 47.03 \\
\hline $\begin{array}{c}\text { Nitrogen } \\
\text { content N\% }\end{array}$ & 3.92 & 0.81 & 2,355 \\
\hline C/N ratio & 12 & 58 & 20 \\
\hline Moisture \% & 49 & 0.52 & 24.3 \\
\hline pH & 5.2 & 7.4 & 6.5 \\
\hline $\begin{array}{c}\text { Density } \\
\text { kglm }\end{array}$ & 311 & 450 & 417.5 \\
\hline
\end{tabular}

Composting units were applied to hold up the waste, the first technique is stationary holding container with dimensions of $20 \mathrm{~cm}$ length, $15 \mathrm{~cm}$ width and $20 \mathrm{~cm}$ height with opened top and meshes sides and bottom to improve aeration as shown in Figure (1). The second technique is rotary cylindrical container of 7 liters that was fixed with central shift to improve the mechanical rotation horizontally with numbers of $1 \mathrm{~cm}$ holes to insure aeration during composting as shown in Figure (2). 


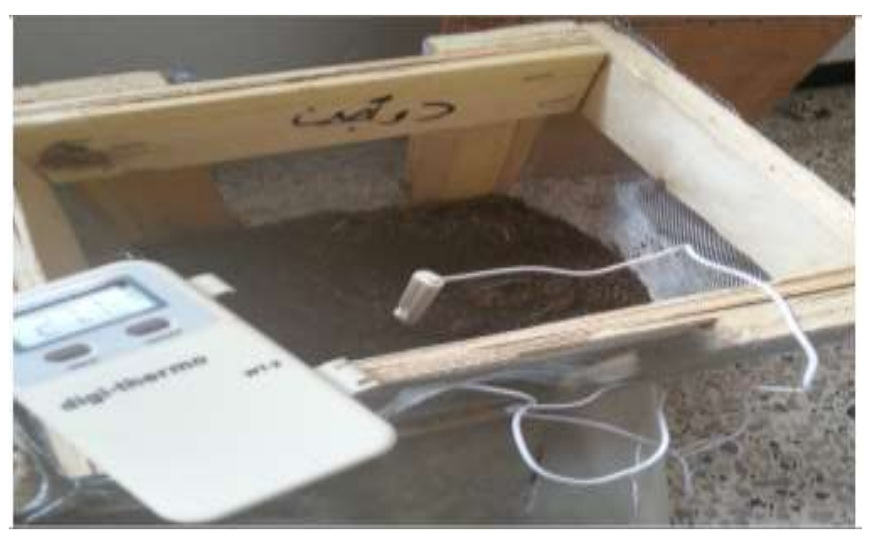

Figure (1). Stationary unit.

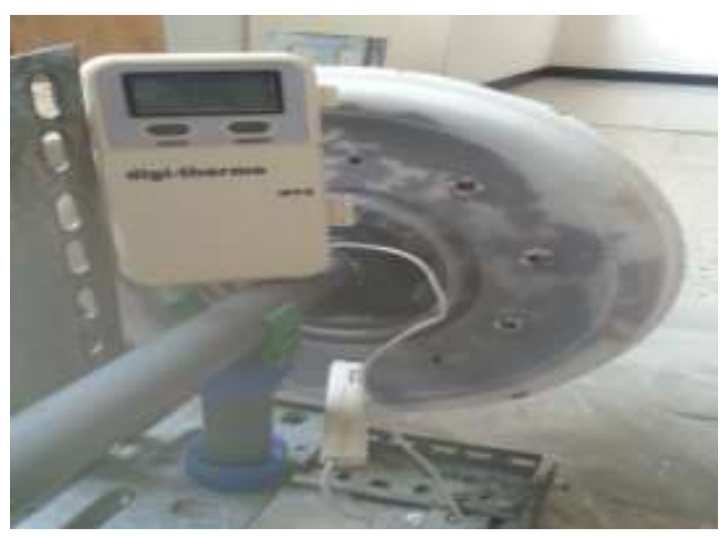

Figure (2). Rotary unit.

Analyses methods $[16,17]$ were done according to the American standard of wood end research laboratory of Ohio State, which is involved in experimental composting process as shown below:

$>\mathrm{pH}$ test using $\mathrm{pH}$ meter type Jenway, Italy by extracting solid sample with distilled water with a ratio of 1:5.

$>$ Temperature measurement of solid bulk during composting using thermo-couple.

$>$ Moisture percent was detected by gravimetric method at drying temperature $105^{\circ} \mathrm{C}$ to estimate weight difference of the solid sample according to the original solid weight:

$$
\text { Moisture } \%=\frac{w_{1}-W_{2}}{W_{1}} X 100
$$

where $\mathrm{W}_{1}$ and $\mathrm{W}_{2}$ are the weights of the solid samples before and after drying, respectively,

Nitrogen content N\% was done for raw feedstock and produced compost using total nitrogen Kjeldahl device.

$>$ Carbon content $\mathrm{C} \%$ or Total carbon content (TOC) was done for dried raw feedstock and produced compost by loss of ignition method using an electrical furnace at $550^{\circ} \mathrm{C}$ and the estimation of the organic matters $(\mathrm{OM})$ was $\mathrm{C} \%$ equals to $54 \%$ of $\mathrm{OM}$.

$$
\begin{array}{r}
O M(L O I) \%=\frac{M_{1}-M_{2}}{M_{1}} X 100 \\
C \%=54 \% O M
\end{array}
$$

where $\mathrm{M}_{1}$ and $\mathrm{M}_{2}$ are weights of the dried solid samples before and after drying, respectively.

$>$ Phosphorus test as $\mathrm{P}_{2} \mathrm{O}_{5}$ test was done after extracting with distilled water using Multi Direct Photometer for multi-parameter analyses (water test equipment) Lovibond, Germany.

$>$ Potassium test as $\mathrm{K}_{2} \mathrm{O}$ was done using XRF, Niton 900, and Thermo Scientific, USA.

$>$ Electrical conductivity (EC) was tested using EC meter type Jenway, Italy by extracting solid sample end compost with distilled water with ratio 1:5.

\section{Results and Discussion}

\subsection{Temperature}

Figure (3) shows recorded temperatures during the composting process when the temperature rises during the first 30 days for both two techniques to reach 59.5 and $55^{\circ} \mathrm{C}$ for rotary and stationary units, respectively. The obtained results comparing with ambient temperature at range $33-34^{\circ} \mathrm{C}$ refer to action solid waste decomposition due to the microbial effect that releases energy as heat during the first and second stage of composting stages (thermal stage).

The temperature was decreased to reach the ambient temperature $\left(28-31^{\circ} \mathrm{C}\right)$ at end of the composting, which is in full agreement with literature $[11,18]$. The composting process is based on the self-heating of waste and therefore, 
it is characterized as bio-thermal process. It occurs as a result of growth and development, especially of thermophilic microorganisms under the aerobic conditions $[2,10]$. During the composting process, the moisture was kept constant by adding sufficient amount of water due to improve humidity of waste, because the activity of the microorganisms during the process is fed by available nutrient provided by organic substances only in aqueous solution. If the moisture content is insufficient, the bio-thermal processes become slow rate, while the excess water will lead to fill the spaces between the bulk of the raw material, which prevents air to pass through the pores and causes oxygen shortage and the composting of the process is becoming under anaerobic conditions [2].

The results show high-temperature degree for the rotary unit than the stationary one due to the aeration factor when starting the thermal process, the sufficient amount of oxygen plays an affecting role in the continuity of the process of aerobic oxidation during composting process to be a successful operation. It is necessary that the air must penetrate to all parts of the waste mass. The composting process is affected by a lot of factors, but the most important factors of degradation of organic compounds are oxygen and water [2].

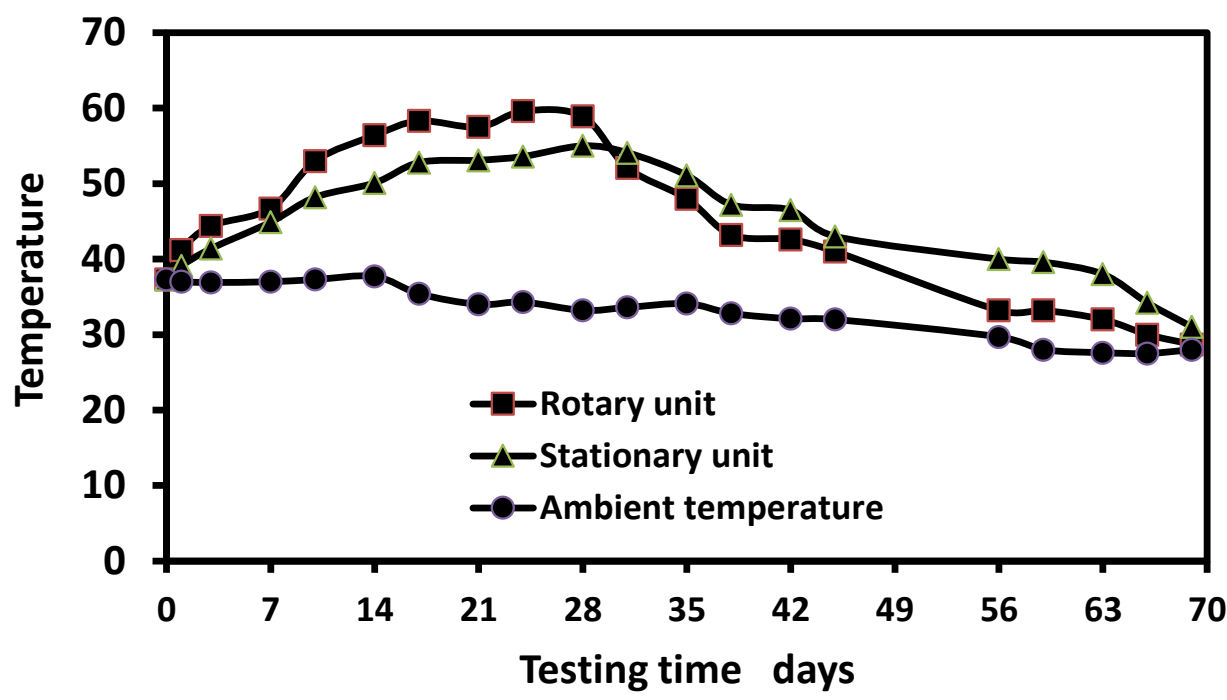

Figure (3). Approach of temperature change during composting process.

\subsection{PH Values}

Figure (4) shows $\mathrm{pH}$ values during the composting process when recorded results are 4.8 and 4.7 for the rotary and stationary units, respectively. The decline in $\mathrm{pH}$ at first week during the first thermo stage is clearly due to action of the decomposition of organic matters in solid bulk produce organic acid which gives acidic conditions during this process, where this conclusion meets with other previous works [10]. In the second thermal stage, the $\mathrm{pH}$ rises, the medium is alkalized to finally stabilize at values close to neutral due to the conversion of nitrogenous compounds into ammonia. 


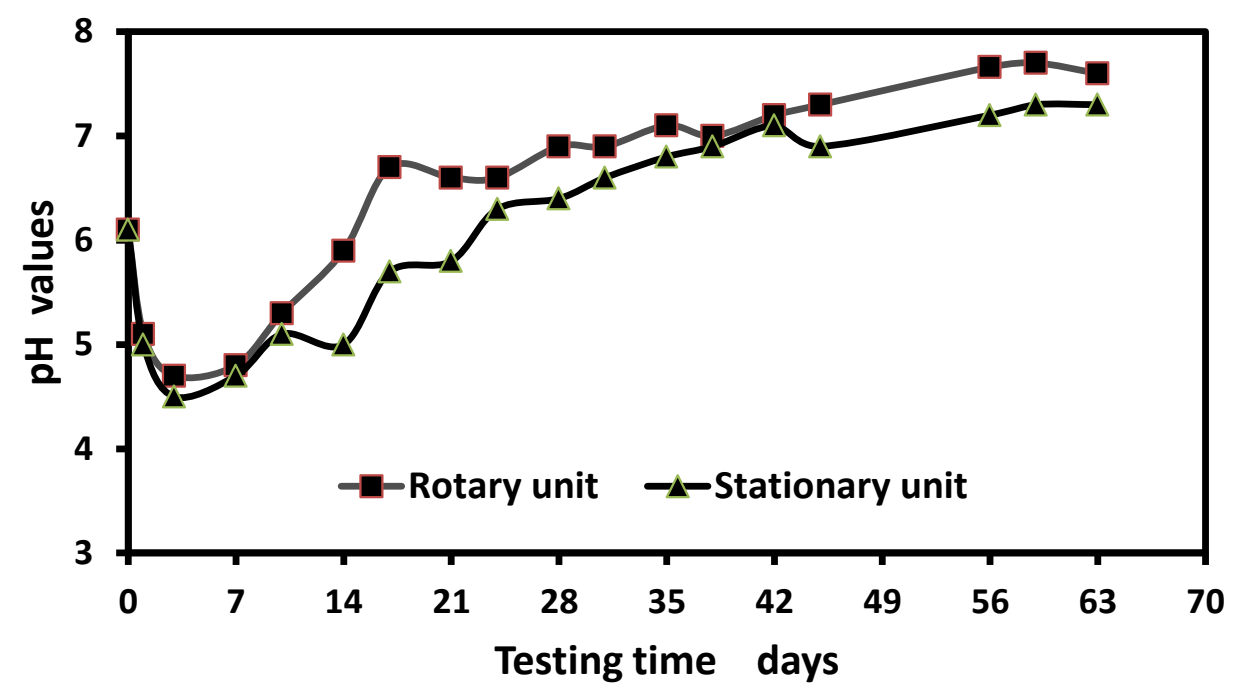

Figure (4). The $\mathrm{pH}$ value change during the composting process.

\subsection{C/N Ratio}

Table (2) shows $\mathrm{C} \%, \mathrm{~N} \%$ and $\mathrm{C} / \mathrm{N}$ ratios in the raw materials. The ratios are $(46.71 \%, 3.92 \%$ and $12 \%)$ and $(47.35 \%, 0.81 \%$ and $58 \%)$ for garbage and chicken manure, respectively. Whereas for 1:1 garbage: chicken manure as feedstock starts composting process given values of $(47.03 \%, 2.35 \%$ and $20 \%)$, where $\mathrm{C} / \mathrm{N}$ ratio for garbage and chicken manure is out of recommended value [10]. The $\mathrm{C} / \mathrm{N}$ ratio of more than $35: 1$ refers to rich in carbon there it is a large amount of carbon-rich materials in the mixture. The process tends to cool and to slow down. While, values less than 15:1 C/N ratio refer to excess nitrogen. There is a higher amount of nitrogen-rich material in the mixture. The process tends to overheat generating odors from the ammonia released, therefore, it is recommended to mix raw materials to obtain acceptable $\mathrm{C} / \mathrm{N}$ ratio to initiate the composting stages.

At the end of composting process for 1:1 garbage: the $\mathrm{C} \%, \mathrm{~N} \%$ and $\mathrm{C} / \mathrm{N}$ ratios for chicken manure of final compost are $(33.05 \%, 1.361 \%$ and $22.278 \%)$ and $(29.73 \%, 1.428 \%$ and $20.8 \%)$ for stationary and rotary units, respectively, where $\mathrm{C} / \mathrm{N}$ ratio is within the range of the recommended values, which are in good consistency with the obtained values of previous published work $[10,15]$. The $\mathrm{C} \%$ was reduced from $47.03 \%$ to $33.05 \%$ and $29.73 \%$, while the N\% was reduced from $2.35 \%$ to $1.361 \%$ and $1.428 \%$ for stationary and rotary units, respectively. These results are attributed to the consumption of the carbon and nitrogen during the biodegradation of organic substances with microorganisms in composting process.

Table (2). The $\mathrm{C} \%, \mathrm{~N} \%$ and $\mathrm{C} / \mathrm{N}$ ratios for the raw material, feedstock and prepared compost.

\begin{tabular}{|c|c|c|c|c|c|}
\hline \multirow[b]{2}{*}{ Parameter } & \multirow[b]{2}{*}{ Garbage } & \multirow{2}{*}{$\begin{array}{l}\text { Chicken } \\
\text { manure }\end{array}$} & \multirow{2}{*}{$\begin{array}{c}\text { Feedstock 1:1 } \\
\text { garbage: Chicken } \\
\text { manure }\end{array}$} & \multicolumn{2}{|c|}{ Final compost } \\
\hline & & & & $\begin{array}{c}\text { Stationary } \\
\text { unit }\end{array}$ & Rotary units \\
\hline $\mathrm{C} \%$ & 46.71 & 47.35 & 47.03 & 33.05 & 29.37 \\
\hline $\mathrm{N} \%$ & 3.92 & 0.81 & 2,355 & 1.361 & 1.428 \\
\hline $\mathrm{C} / \mathrm{N}$ & 12 & 58 & 20 & 22.278 & 20.8 \\
\hline
\end{tabular}

\subsection{NPK and Electrical Conductivity Values}

Table (3) shows nitrogen, phosphorus and potassium percentages, where NPK is an indicator and electrical conductivity (EC) to show the acceptable salinity of the produced compost. 
Table (3). The NPK and electrical conductivity values.

\begin{tabular}{|c|c|c|c|c|}
\hline $\begin{array}{c}\text { Composting } \\
\text { technique }\end{array}$ & $\mathbf{N \%}$ & $\mathbf{P \%}$ & $\mathbf{K \%}$ & $\begin{array}{c}\mathbf{E C} \\
(\mathbf{m S} / \mathbf{c m})\end{array}$ \\
\hline Rotary unit & 1.428 & 1.719 & 4.508 & 5.5 \\
\hline Stationary unit & 1.361 & 0.419 & 3.884 & 6.04 \\
\hline
\end{tabular}

The obtained NPK results show acceptable values (1.428:1.719:4.508) \% for rotary unit and (1.361:0.419:3.884) $\%$ for stationary unit with in good coincidence with the previous work which recorded a range of NPK $(0.3-4.19 \%$, $0.2-1.6 \%$ and $0.2-6.18 \%)$ [19].

For EC values, the obtained results are $5.5 \mathrm{mS} / \mathrm{cm}$ for rotary unit and $6.04 \mathrm{mS} / \mathrm{cm}$ for stationary unit, which is in the range of the recommended standard EC values $(0-10 \mathrm{mS} / \mathrm{cm})[11]$ where $\mathrm{EC}$ value ranges from $2-5 \mathrm{mS} / \mathrm{cm}$ and it is considered an average salinity and must be mixed with soil with a ratio of 2:5 for all farming applications, while EC values (5-10) $\mathrm{mS} / \mathrm{cm}$ is considered medium to high salinity and must be mixed with a ratio of 3:10 where soluble salt level (salinity) in the sample is estimated based on the measurements of the electrical conductivity [20]. Low values of NPK can indicate a lack of available minerals, while high values are indicating a large amount of soluble minerals that may inhibit biological activity or cause problems with land applications if large quantities of the materials are used $[16,17]$.

\section{Conclusions}

The study shows good results of the transformation of biodegradable organic matters that discharged as refused solid waste. The study applied management solid waste by the composting process option as applicable method and easy operation technique by using the stationary and rotary units with recommended results where the $\mathrm{pH}$ values were reported at final compost with ranges of 7.3 and 7.6. The $\mathrm{C} / \mathrm{N}$ ratio values are 20.8 and 22.27, and acceptable NPK values (1.428:1.719:4.508) \% and (1.361:0.419:3.884) \%. The salinity indicator has been explained as EC values were 5.5 and $6.04 \mathrm{mS} / \mathrm{cm}$ and they are recommended according to standards values.

\section{References}

[1] M. Farrell, and D.L. Jones, "Critical evaluation of municipal solid waste composting and potential Compost markets," Journal of Bio Resource Technology, vol. 100, pp. 4301-4310, 2009.

[2] I. I. Krstić, J. Radosavljević, A. Đorđević, D. Avramović, and A. Vukadinović, "Composting as biodegradable waste management," Working and Living Environmental Protection, vol. 15, no. 2, pp. 135 - 145, 2018.

[3] A. M. Taiwo, "Composting as sustainable waste management technique in developing countries, " Journal of Environmental Science and Technology, vol.4, no.2, pp.93-103, 2011.

[4] A.K. Pathak, M.M. Singh, and V. Kumar, "Composting of municipal solid waste: A sustainable waste management technique in Indian cities- A Review," International Journal of Current Research, Vol. 3, Issue, 12, pp.339-346, 2011.

[5] M. S. Ayilara, O. S. Olanrewaju, O. O. Babalola, and O. Odeyemi, "Waste management through composting: challenges and potentials," Journal of Sustainability, vol.12, no.11, pp.1-23, 2020.

[6] N. G. Turan, S. oruh, A. Akdemir, and O. N. Ergun, "Municipal solid waste management strategies in Turkey," Journal of Waste Management, vol. 29, pp. 465-469, 2009.

[7] S. Wang, and Y. Wu, "Hyperthermophilic Composting Technology for Organic Solid Waste Treatment: Recent Research Advances and Trends," Journal of Processes, vol. 9, pp. 675-686, 2021.

[8] P. F. Rizzo, V. D. Torre, N. I. Riera •, D. Crespo, R. Barrena, and A. Sa'nchez, "Co-composting of poultry manure with other agricultural wastes: process performance and compost horticultural use," Journal of Material Cycles and Waste Management, vol. 17, pp. 42-50, 2015.

[9] B. A. Ankidawa, and E. Nwodo, "Recycling of biodegradable waste using composting technique," Journal of Environmental Science and Resources Management, vol.4, pp. 40-49, 2012.

[10] P. Romanm M. M. Martinez, and A. Pantoja, "Farmers compost handbook," Food and Agriculture Organization of the United Nations FAO, 2015. 
[11] H. Jalalipour, N. Jaafarzadeh, G. Morscheck, S. Narra, and M. Nelles, "Potential of producing compost from source-separated municipal organic waste,", "Journal of Sustainability, vol. 12, no. 22, pp.1-17, 2020.

[12] T. Sayara, R. B. Salimia, F. Hawamde and A. Sánchez, "Recycling of organic wastes through composting: process performance and compost application in agriculture," Journal of Agronomy, vol. 10, no.11, pp.1838, 2020.

[13] W. G. André, J. G. Fuchs, M. 1 Raviv and A. J. Termorshuizen, "Handbook for composting and compost use in organic horticulture," European union -Netherland, 2016.

[14] S. M. Tiquia, and N. F. Tam, "Characterization and composting of poultry litter in forced-aeration piles," Journal of Process Biochemistry, vol, 37, pp. 869-880, 2002.

[15] Y. A. Argun, A. Karacali, U. Calisir, and N. Kilinc, "Composting as a waste management method," Journal International Environmental Application \& Science, vol. 12, no.3, pp. 244-255, 2017.

[16] A. Ameen, J. Ahmad, N. Munir and S. Raza, "Physical and chemical analyses of compost to check its maturity and stability," European Journal of Pharmaceutical and Medical Research, vol., 3, no.5, pp. 84-87, 2016.

[17] W. F. Brinton, J. Bonhotal, and T. Fiesinger, "Compos sampling for nutrient and quality parameters" Journal of Compost Science and Utilization. Vol.20, no.3, pp.141-149, 2012.

[18] M. Rihani, D. Malamis b, B. Bihaoui, S. Etahiri, M. Loizidou, and O. Assobhei, "In-vessel treatment of urban primary sludge by aerobic composting," Journal of Bioresource Technology, vol. 101 pp.5988-5995, 2010.

[19] M. M. Manyuchi, and A. Phiri. "Vermicomposting in solid waste management" International Journal of Scientific Engineering and Technology, vol.2, no.12, pp. 1234-1242, 2013.

[20] H. Peña, H. Mendoza, F. Diánez 2 and M. Santos, "Parameter selection for the evaluation of compost quality" Journal of Agronomy vol. 10, no.10, 2020. 